\title{
The effects of increased milking frequency during early lactation on milk yield and milk composition on commercial dairy farms
}

\author{
F. Soberon, ${ }^{\star}$ C. M. Ryan, ${ }^{\star}$ D. V. Nydam, $†$ D. M. Galton, ${ }^{\star}$ and T. R. Overton ${ }^{\star 1}$ \\ *Department of Animal Science, and \\ †Department of Population Medicine and Diagnostic Sciences, Cornell University, Ithaca, NY 14853
}

\begin{abstract}
Increased milking frequency (IMF) during early lactation has the potential for carryover responses following the return to normal herd milking frequency. The objective was to determine the consistency of response of cows in commercial dairy farms to IMF during early lactation. Cows $(\mathrm{n}=398)$ were assigned randomly at calving within each of the 4 participating farms to 1 of 2 treatments. The control group was milked twicedaily $(2 \times)$ during the entire lactation. The IMF group was milked 4 -times daily $(4 \times)$ starting on $\mathrm{d} 1$ to 7 , depending on farm, until $d 21$ postcalving and $2 \times$ thereafter. Cows in the IMF group were milked at the beginning and again at the end of the normal milking routine. Milking intervals differed across the farms for the $4 \times$ cows with a minimum interval of $3.5,4.0,5.0$, and $6 \mathrm{~h}$ for each of the 4 farms, respectively. The milk yield of cows subjected to IMF increased by $2.2 \pm 0.4$ $\mathrm{kg} / \mathrm{d}$ during the first $7 \mathrm{mo}$ of lactation. Interactions of treatment with lactation group (primiparous vs. multiparous) were not significant. Although percentages of fat and protein in milk were decreased by early lactation $\operatorname{IMF}(3.69 \% \pm 0.03$ fat and $3.05 \% \pm 0.02$ true protein for control vs. $3.57 \% \pm 0.03$ fat and $2.99 \%$ \pm 0.02 true protein for IMF), overall yields of protein were increased by $\operatorname{IMF}(1.02 \pm 0.01$ vs. $0.98 \pm 0.01$ $\mathrm{kg} / \mathrm{d}$ ). Early lactation IMF did not affect udder health as assessed by somatic cell count linear score. Cows subjected to IMF were 1.4 times more likely classified as subclinically ketotic than the control cows. Early lactation IMF has the potential to increase milk yield on commercial dairy farms. Although the direction of response was the same on all farms, the magnitude of the response was different among farms and appears influenced by management practices specific to each farm, which included, but were not limited to, housing system, stocking density, nutrition, genetics, and other covariates differing among farms.
\end{abstract}

Received July 21, 2010.

Accepted May 4, 2011.

${ }^{1}$ Corresponding author: tro2@cornell.edu
Key words: increased milking frequency, lactation, dairy cow

\section{INTRODUCTION}

The effects of frequent milking on the performance of dairy cows have been widely studied (Wall and McFadden, 2008). For many years, researchers focused on the effect of increased milking frequency (IMF) during the entire lactation, consistently reporting increased yields of milk and milk components when cows were milked more frequently (Barnes et al., 1990; Klei et al., 1997; Smith et al., 2002). Erdman and Varner (1995) compiled data from 19 studies and concluded that cows milked $3 \times$ daily yielded an additional $3.5 \mathrm{~kg} / \mathrm{d}$ of milk, $92 \mathrm{~g} / \mathrm{d}$ of fat, and $82 \mathrm{~g} / \mathrm{d}$ of protein compared with cows milked $2 \times$.

Studies demonstrated the potential for IMF applied during early lactation only to affect overall lactational milk yield. Researchers have reported carryover effects on milk yield and milk components in cows milked $4 \times$ or $6 \times$ during the first 21 or $42 \mathrm{~d}$ postpartum, followed by a return to a $2 \times$ or $3 \times$ milking routine (Bar-Peled et al., 1995; Hale et al., 2003; Dahl et al., 2004). Other studies demonstrated either minimal carryover effects (Fernandez et al., 2004) or negative effects (VanBaale et al., 2005) of IMF during early lactation on subsequent milk yield.

Most experiments conducted to date included either small numbers of cows per treatment or were conducted on only 1 dairy farm. Therefore, the objective was to determine the effect of increased milking frequency during early lactation on dairy cow performance across several commercial dairy farms to evaluate the consistency of responses under commercial dairy farm conditions.

\section{MATERIALS AND METHODS}

\section{Herd Enrollment, Treatments, and Housing}

Holstein cows $(\mathrm{n}=398)$ from 4 commercial dairy farms in central and northern New York were assigned randomly at calving within each of the farms to either a $2 \times$ or $4 \times$ daily milking frequency treatment for the 
Table 1. Summary of number of primiparous (first-lactation) and multiparous (2+-lactation) cows on each farm that were milked $2 \times$ (control) for the entire lactation or $4 \times$ (increased milking frequency, IMF) for the first $21 \mathrm{~d}$ postpartum, followed by $2 \times$ for the remainder of the period ${ }^{1}$

\begin{tabular}{|c|c|c|c|c|c|c|c|}
\hline Farm & $\begin{array}{l}\text { First-lactation } \\
\text { cows (total), n }\end{array}$ & $\begin{array}{l}\text { 2+-lactation } \\
\text { cows (total), n }\end{array}$ & $\begin{array}{l}\text { First-lactation } \\
\text { cows (control), n }\end{array}$ & $\begin{array}{c}2+\text {-lactation } \\
\text { cows (control), } \mathrm{n}\end{array}$ & $\begin{array}{l}\text { First-lactation } \\
\text { cows (IMF), n }\end{array}$ & $\begin{array}{l}\text { 2+-lactation } \\
\text { cows (IMF), n }\end{array}$ & $\begin{array}{c}\text { Interval } \\
4 \times^{2}\end{array}$ \\
\hline 1 & $35(1)$ & $68(3)$ & $19(1)$ & $31(1)$ & 16 & $37(2)$ & 4 \\
\hline 4 & 36 & $65(6)$ & 16 & $35(2)$ & 20 & $30(4)$ & 6 \\
\hline Total & $147(3)$ & $251(20)$ & $73(2)$ & $122(9)$ & $74(1)$ & $129(11)$ & \\
\hline
\end{tabular}

${ }^{1}$ The number in parentheses represents the number of cows removed from the experiment.

${ }^{2}$ Interval $4 \times$ is the number of hours between the first and second milkings, also equal to the number of hours between the third and fourth milkings. The interval between the first and third milkings of the $4 \times$ treatment was $12 \mathrm{~h}$ for all farms except for farm 2 , which had a 10-h interval between the first and third milking. The interval between milkings for $2 \times$ cows was the same as for the first and third milking of $4 \times$ cows.

${ }^{3}$ The interval between the third and fourth milking was 45 min shorter than between the first and second milking of $4 \times$ cows.

first $21 \mathrm{~d}$ postpartum. After d 21 postpartum, all cows were milked $2 \times$ for the remainder of the experiment (with one exception to be described later). Milking and health management was conducted according to each of the herds' protocols and culling decisions were made by the farm owners. The numbers of primiparous and multiparous cows assigned to the treatments on each farm as well as the number of animals removed from the experiment on each treatment are in Table 1. Animals were removed from the experiment if they died or were sold according to the standard operating procedures on each farm. The number of cows removed was not different among treatments, but was greater for multiparous cows compared with primiparous cows.

On farm 1 , cows $(\mathrm{n}=103)$ were housed in separate pens in a freestall barn and milked $2 \times$ or $4 \times$ from $d 3$ postpartum through d 21 postpartum. After d 21, all cows were housed in the same pens sorted by lactation group and milked $2 \times$ for the remainder of lactation. Cows were milked at 0315 and $1515 \mathrm{~h}$; cows assigned to the $4 \times$ treatment were milked again at 0715 and 1915 h. Four cows did not finish the experiment and their data were not used.

On farm 2 , cows $(\mathrm{n}=105)$ were housed in a freestall barn and the fresh cow pen was divided into 2 parts. All cows were kept in an observation pen during the first $7 \mathrm{~d}$ postpartum and milked $2 \times$ during this time, after $7 \mathrm{~d}$ they were moved to the fresh pen and started their respective treatments. All cows were milked at 0245 and $1330 \mathrm{~h}$; the cows milked $4 \times$ were milked again at 0800 and $1800 \mathrm{~h}$. In addition to the treatment in which cows were milked $4 \times$ for $21 \mathrm{~d}$, an additional group of cows $(\mathrm{n}=50)$ continued the $4 \times$ treatment until d 60 . Previous management practices at this farm included milking fresh cows $4 \times$ during the first $60 \mathrm{~d}$ postpartum; the producers wanted to compare their current management practice to the treatments described in this experiment. After completion of the $4 \times$ milking treatment at either 21 or $60 \mathrm{~d}$ postpartum, cows were moved to a $2 \times$ milking group for the remainder of lactation. Two cows did not finish the experiment and 1 cow was removed from the group milked $4 \times$ for $60 \mathrm{~d}$.

On farm 3 , cows $(n=89)$ were housed and milked in a tie-stall barn and milked either $2 \times$ or $4 \times$ starting $1 \mathrm{~d}$ after calving and continuing through $21 \mathrm{~d}$ postpartum. After d 21, all cows were moved to a freestall barn and milked $2 \times$ for the remainder of lactation. All cows were milked at 0300 and $1500 \mathrm{~h}$; cows assigned to the $4 \times$ treatment were milked again at 0630 and $1830 \mathrm{~h}$. Eleven cows did not finish the experiment.

On farm 4 , cows $(\mathrm{n}=101)$ were housed in a divided pen in a freestall barn starting $1 \mathrm{~d}$ after calving and milked $2 \times$ or $4 \times$ for the first $21 \mathrm{~d}$ postpartum. After $\mathrm{d}$ 21 , all cows were housed together in a pen and milked $2 \times$ for a minimum of 5 mo of lactation before the entire herd was changed to a $3 \times$ milking scheme. Cows were milked at 0600 and $1800 \mathrm{~h}$; cows assigned to the $4 \times$ treatment were milked again at 1200 and $2400 \mathrm{~h}$. Six cows did not finish the experiment.

All cows were fed a TMR formulated by the nutritionist of each farm; cows within a farm received the same diet regardless of treatment.

\section{Sampling and Laboratory Analysis}

Milk yield was measured at monthly test days by DHI technicians and milk samples collected on the same day were analyzed for fat, true protein, SCC, and milk urea $\mathrm{N}$ using mid-infrared spectroscopy according to AOAC (2000) methods (Dairy One Cooperative, Ithaca, NY).

Body condition score was assessed by 1 person using a 1 (thin) to 5 (fat) scale (Wildman et al., 1982). The BCS of each cow was assessed once during the month before calving, once during the first month postcalving, and 1 more time between their second and fourth month postcalving ( $88 \pm 8 \mathrm{DIM})$ on each farm.

A single blood sample was collected from each cow during the first $21 \mathrm{~d}$ postpartum; blood was collected 
from the coccygeal vein or artery into evacuated test tubes without anticoagulant (Vacutainer; Becton Dickinson, Franklin Lakes, NJ). Samples were placed on ice for transport to the laboratory where they were centrifuged $(1,380 \times g$ for $15 \mathrm{~min})$. Serum was transferred to polycarbonate test tubes and frozen at $-20^{\circ} \mathrm{C}$ until subsequent analysis for NEFA and BHBA. Serum NEFA concentrations were analyzed by enzymatic analysis (NEFA-C; WAKO Pure Chemical Industries, Osaka, Japan) using modifications described by McCutcheon and Bauman (1986). Serum BHBA concentrations were determined by enzymatic analysis (BHBA dehydrogenase; kit \#310; Sigma Chemical Co., St. Louis, MO).

\section{Statistical Analysis}

Farms 1, 2, and 3 all had milk yield and milk composition information for at least 7 monthly test days for cows enrolled in the study. The owner of farm 4 began whole-herd $3 \times$ milking 6 mo after the experiment commenced. Therefore, data for milk yield and composition from the first 7 monthly test days of lactation from the first 3 farms and 5 monthly test days from the fourth farm, as well as BCS from all farms, were subjected to ANOVA for a completely randomized design with repeated measures using the MIXED procedure of SAS (SAS Institute, 2010). The model included the random effect of farm and the fixed effects of treatment, lactation group (primiparous vs. multiparous) and time (monthly test day) along with all 2-way and 3-way interactions. The denominator degrees of freedom were adjusted using the method of Kenward Rogers (Chapa et al., 1995), and each model was tested using 4 different covariance structures (autoregressive order one, autoregressive order one with heterogeneous variance, compound symmetry, and compound symmetry with heterogeneous variance). The model and covariance structure with the lowest Akaike's Information Criterion was selected; in almost all cases, this was the model using the autoregressive order one with heterogeneous variance covariance structure. In the analysis of BCS, all 4 farms were included and precalving BCS was used as a covariate.

Data for concentrations of BHBA and NEFA in serum were analyzed using the MIXED procedure of SAS (SAS Institute, 2010). Variables in the model included treatment, lactation group, and the 2-way interaction. Farm was included in the model as a random effect. These data were evaluated for the number of cows categorized as subclinically ketotic (BHBA $>10 \mathrm{mg} /$ dL; Ospina et al., 2010) and having high NEFA concentrations (NEFA > $700 \mu \mathrm{Eq} / \mathrm{L}$; Ospina et al., 2010) using the LOGISTIC procedure of SAS (SAS Institute, 2010). Terms in the model initially included treatment, lactation group, and the 2-way interaction thereof. Lactation group and the interaction of lactation group and treatment were not significant, so these terms were taken out of the model and 2 by 2 contingency table analysis was used to calculate the relative risks and $95 \%$ confidence intervals for each of the above mentioned metabolic conditions with the $P$-value determined using chi-squared analysis (Dean et al., 1994).

Data were analyzed by farm, for which information from 7 monthly test days was used in the analyses of farms 1, 2, and 3; farm 2 had an additional treatment in which cows were milked $4 \times$ for $60 \mathrm{~d}$ and then returned to $2 \times$ milking; therefore, the independent analysis of data from farm 2 included 2 IMF treatments plus control. The analysis of farm 4 included data from 5 test days because of the management decision to milk all cows $3 \times$ before the study had concluded. The statistical analysis by farm was conducted for a completely randomized design with repeated measures using the MIXED procedure of SAS (SAS Institute, 2010). Variables in the model included treatment, lactation group, test day, and all 2-way and 3-way interactions. Covariance structures were evaluated as described above.

Significance was declared at $P<0.05$ and trends were declared at $0.05<P<0.10$. Least squares means are presented throughout.

\section{RESULTS AND DISCUSSION}

All 4 farms had notable differences in management, including housing, milking interval, herd size, and pen size. Regardless of these differences, all farms exhibited similar responses to IMF. Across all farms and cows $(\mathrm{n}=398)$, cows subjected to IMF produced $2.2 \pm 0.4$ $\mathrm{kg} / \mathrm{d}$ more milk over 7 monthly test days $(32.4 \pm 0.4$ $\mathrm{kg} / \mathrm{d}$ for control vs. $34.6 \pm 0.4 \mathrm{~kg} / \mathrm{d}$ for IMF; $P<0.01$; Table 2 and Figure 1). The overall response to IMF was comparable in both primiparous and multiparous cows, as indicated by the lack of an interaction of treatment and lactation group $(P=0.53$; Table 2$)$.

Overall responses to IMF in this experiment supported Hale et al. (2003), who reported an increase of $3 \mathrm{~kg} / \mathrm{d}$ over a 308-d lactation in response to the same $4 \times / 2 \times$ IMF scheme in multiparous cows. Other reported responses to IMF frequencies range from negligible to $>6 \mathrm{~kg} / \mathrm{d}$ throughout the lactation (Wall and McFadden, 2008). In the present study, the overall interaction of treatment by month was significant $(P=$ 0.01; Figure 1), consistent with the concept that milk yield responses would be greater during the period of IMF and decreased during the period following IMF. Separate analysis of the results from mo 2 to 7 (after the period of IMF) suggested that cows previously subjected to IMF yielded $1.7 \pm 0.4 \mathrm{~kg} / \mathrm{d}$ more milk than 
Table 2. Least squares means and standard errors for milk yield and milk components for primiparous (first-lactation) and multiparous (2+-lactation) cows during the first 7 test days of lactation for cows from the 4 farms that were milked either $2 \times$ (control) for the entire lactation or $4 \times$ (increased milking frequency, IMF) for the first $21 \mathrm{~d}$ postpartum, followed by $2 \times$ for the remainder of the lactation

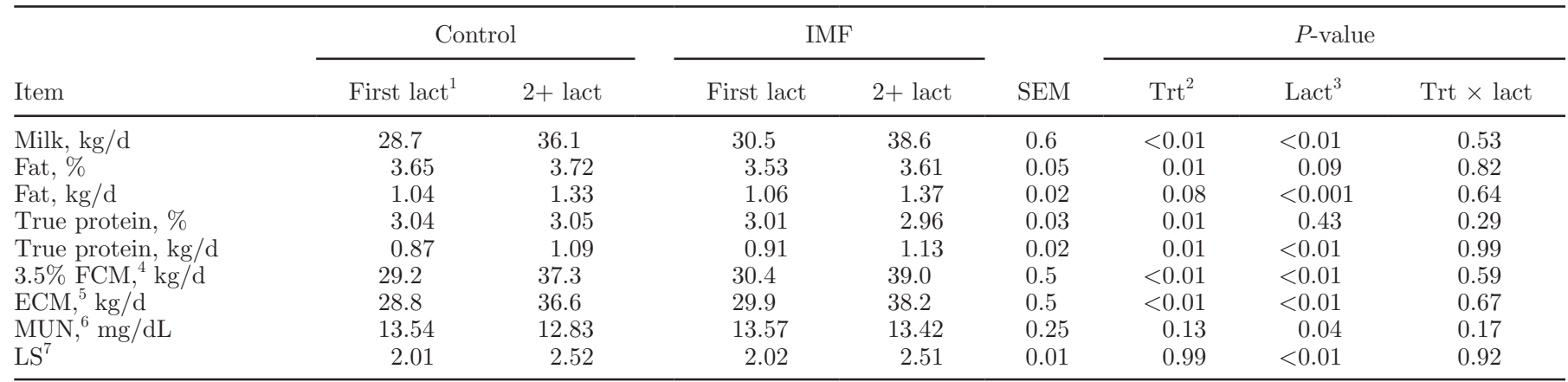

${ }^{1}$ Lact $=$ lactation.

${ }^{2}$ Trt $=$ treatment; refers to differences between treatments when cows from both lactation groups are included.

${ }^{3}$ Refers to differences between lactation groups when cows from both treatments are included.

${ }^{4}$ Formula for $3.5 \% \mathrm{FCM}=[(0.4324 \times \mathrm{kg}$ of milk $)+(16.216 \times \mathrm{kg}$ of fat $)]$.

${ }^{5}$ Value corrected for $3.5 \%$ fat and $3.2 \%$ true protein $=[(0.3246 \times \mathrm{kg}$ milk $)+(12.86 \times \mathrm{kg}$ of fat $)+(7.04 \times \mathrm{kg}$ of true protein $)]$.

${ }^{6}$ Values for MUN were from 3 farms; farm 2 did not test for MUN.

${ }^{7}$ Linear score, calculated as the log of SCC.

did controls $(32.7 \pm 0.4$ vs. $34.4 \pm 0.4 \mathrm{~kg} / \mathrm{d} ; P<0.01)$. This persistent increase in milk yield supports Hale et al. (2003), Dahl et al. (2004), and Wall and McFadden (2007a), but not Fernandez et al. (2004), VanBaale et al. (2005), and Soberon et al. (2010). Reasons for the lack of carryover responses in Fernandez et al. (2004) and Soberon et al. (2010) are not known; however, the lack of response to IMF in the VanBaale et al. (2005) study was likely related to significantly increased $(\sim 6$ h vs. $3 \mathrm{~h}$ ) time away from the pen for cows milked $6 \times$. Within the 4 farms evaluated for this study, time away from the pen during milking ranged from $0 \mathrm{~h}$ for cows housed and milked in a tie-stall barn to over $4 \mathrm{~h} / \mathrm{d}$. Within this range of time spent away from their pen, cows subjected to IMF managed to exhibit a consistently increased milk response.

Milk composition data are reported for all cows (n $=398)$. Percentages of both milk fat and true protein were decreased with IMF treatment $(3.69 \% \pm 0.03$ fat and $3.05 \% \pm 0.02$ true protein for control vs. $3.57 \% \pm$ 0.03 fat and $2.99 \% \pm 0.02$ true protein for IMF; $P=$ 0.01 ; Table 2). Early lactation IMF tended to increase

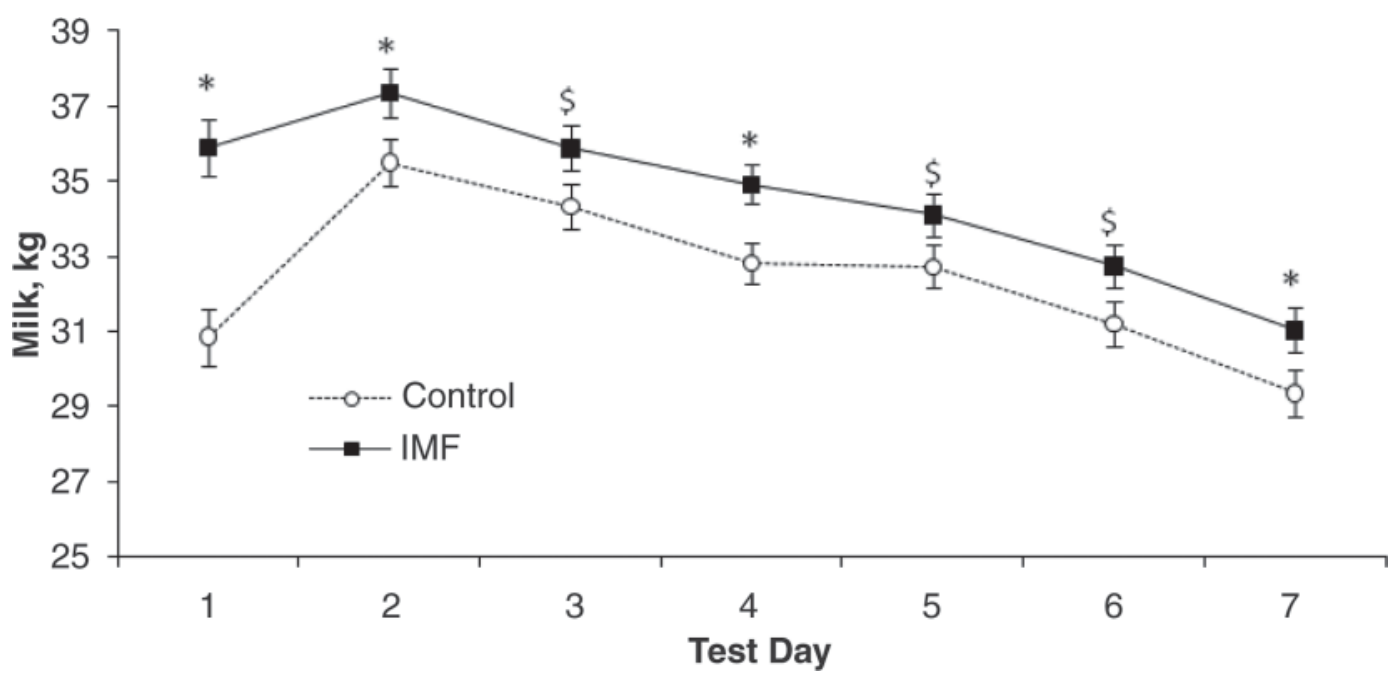

Figure 1. Least squares means and standard errors for milk yield during the first 7 test days of lactation for cows in 4 commercial dairy farms in which cows were milked either $2 \times$ (control) for the entire lactation or $4 \times$ (increased milking frequency, IMF) for the first $21 \mathrm{~d}$ postpartum, followed by $2 \times$ for the remainder of the lactation $(\mathrm{n}=398)$. The $P$-value for the effect of treatment was $<0.01$ and the interaction of treatment and month was 0.01 . Test days marked with an asterisk denote $P<0.05$; test days marked with $\$$ denote $P<0.09$. 


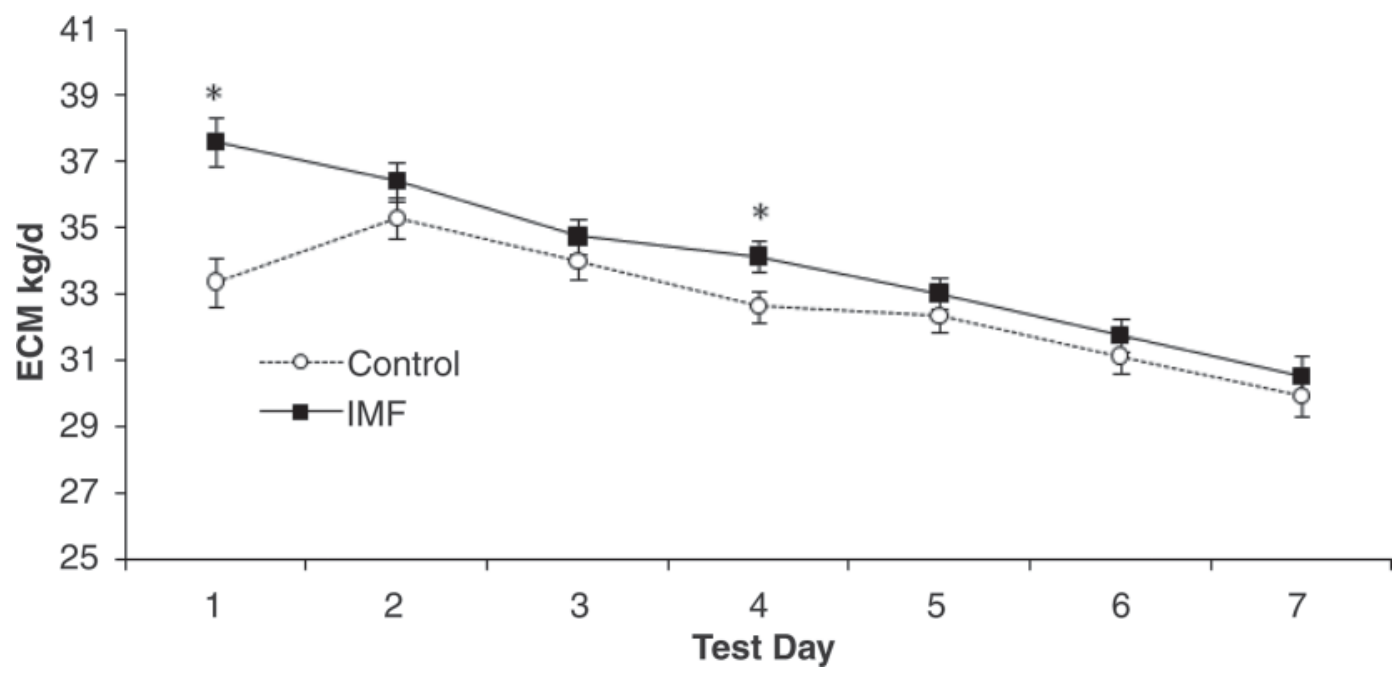

Figure 2. Least squares means and standard errors for yield of ECM (corrected to $3.5 \%$ fat and $3.2 \%$ true protein) during the first 7 test days of lactation for cows milked either $2 \times$ (control) for the entire lactation or $4 \times$ (increased milking frequency, IMF) for the first $21 \mathrm{~d}$ postpartum, followed by $2 \times$ for the remainder of the lactation $(\mathrm{n}=398)$. The $P$-value for the effect of treatment was $<0.01$ and the interaction of treatment and month was $<0.01$. Test days marked with an asterisk denote $P<0.05$.

milk fat yield $(1.18 \pm 0.01$ vs. $1.21 \pm 0.01 \mathrm{~kg} / \mathrm{d} ; P=$ $0.08)$ and the interaction of treatment and month for milk fat yield tended toward significance $(P=0.08)$ such that differences were greater during the first test day. Similarly, overall yield of true protein in milk was increased by early lactation IMF $(1.02 \pm 0.01$ vs. 0.98 $\pm 0.01 \mathrm{~kg} / \mathrm{d} P=0.01$ ) and a treatment by month interaction similar to that for fat yield existed for true protein $(P=0.08)$. These findings support Bar-Peled et al. (1995), who observed a decrease in milk fat and milk protein percentages, but an overall increase in milk fat and milk protein yields. Hale et al. (2003) determined that percentages of milk fat and true protein were decreased by IMF, resulting in no change in yields of fat and protein for cows subjected to IMF.

Consistent with the increased yields of milk, fat, and true protein by cows subjected to early lactation IMF, overall yields of $3.5 \% \mathrm{FCM}$ and ECM were increased $(P$
$<0.01$ ) by early lactation IMF compared with $2 \times$ controls (Table 2). In cows subjected to IMF, 3.5\% FCM yield was increased by $1.5 \pm 0.3 \mathrm{~kg} / \mathrm{d}(34.7 \pm 0.3$ vs. $33.2 \pm 0.3 \mathrm{~kg} / \mathrm{d}$ ) and ECM yield was increased by $1.3 \pm$ $0.3 \mathrm{~kg} / \mathrm{d}(34.0 \pm 0.3 \mathrm{vs} .32 .7 \pm 0.3 \mathrm{~kg} / \mathrm{d})$. These results are in contrast to those of Hale et al. (2003), who did not detect differences in FCM between IMF and control cows over a 10 -wk period. An interaction of treatment by month existed for both FCM and ECM, suggesting such that the differences from IMF were mainly attributable to the period of IMF early in lactation, and the differences in FCM and ECM yields decreased between treatments as lactation progressed. Energy-corrected milk yields by month for cows assigned to each treatment are presented in Figure 2.

Only 3 farms tested for MUN. Of these farms, no differences were detected between treatments $(P=0.13)$, but primiparous cows had higher concentrations of

Table 3. Least squares means and standard errors for milk yield for primiparous (first-lactation) and multiparous (2+-lactation) cows and the overall means (primiparous and multiparous cows) during the first 7 test days of lactation for cows milked either $2 \times$ (control) for the entire lactation or $4 \times$ (increased milking frequency, IFM) for the first $21 \mathrm{~d}$ postpartum, followed by $2 \times$ for the remainder of the lactation on each of the 4 farms analyzed

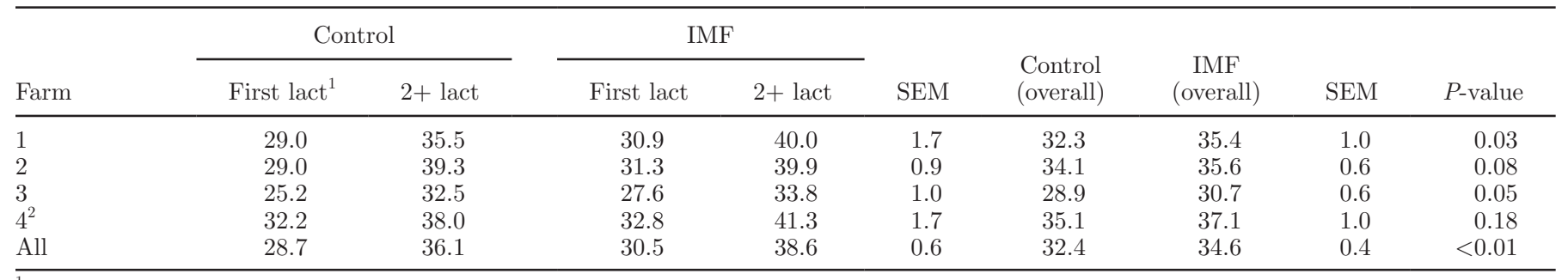

${ }^{1}$ Lact $=$ lactation.

${ }^{2}$ Only 5 monthly test days were use for this farm. 
MUN compared with multiparous cows $(13.6 \pm 0.2$ vs. $13.1 \pm 0.2 \mathrm{mg} / \mathrm{dL} ; P=0.04)$. Somatic cell linear scores were used to assess udder health and possible increases in the prevalence of mastitis. Somatic cell linear score was higher $(P<0.01)$ in multiparous compared with primiparous cows $(2.0 \pm 0.1$ vs. $2.5 \pm 0.1)$; however, no differences were observed between treatments $(P=$ 0.99; Table 2), suggesting lack of negative or positive effects from IMF on udder health. These findings contrast those from Smith et al. (2002) as well as those from Klei et al. (1997) who reported decreased linear scores (calculated as the log of SCC) and SCC when cows were milked $3 \times$ compared with $2 \times$. Dahl et al. (2004) reported that cows subjected to a $6 \times / 3 \times$ milking scheme had decreased SCC during the first 3 mo of lactation compared with $3 \times$ controls.
Data analysis by farm allowed the determination of differences in the magnitude of the response to IMF treatment among farms (Table 3). Differences among farms, when analyzed by lactation group, ranged from 0.5 to $4.4 \mathrm{~kg} / \mathrm{d}$. In farm 1 , IMF increased milk production during the first 7 monthly test days by $3.1 \mathrm{~kg} / \mathrm{d}$ $(32.3 \mathrm{~kg} / \mathrm{d}$ vs. $35.4 \mathrm{~kg} / \mathrm{d} \pm 1.0 ; P=0.03)$ In this farm, multiparous cows had a greater response to IMF than did primiparous cows (12\% increase for multiparous cows vs. $6 \%$ increase in primiparous cows; Table 3 ). Primiparous and multiparous cows were housed together during the first $21 \mathrm{~d}$ postpartum; as discussed later, this may have contributed to the lower response of primiparous cows to IMF. Cows subjected to IMF for $21 \mathrm{~d}$ postpartum on farm 2 tended $(P<0.08)$ to have increased milk yield during the first 7 mo of lacta-

Table 4. Least squares means and standard errors for BCS, BHBA concentrations, and NEFA concentrations for primiparous (first-lactation) and multiparous (2+-lactation) cows for cows milked either $2 \times$ (control) for the entire lactation or $4 \times$ (increased milking frequency, IFM) for the first $21 \mathrm{~d}$ postpartum, followed by $2 \times$ for the remainder of the period

\begin{tabular}{|c|c|c|c|c|c|c|c|c|c|}
\hline Variable and farm & \multicolumn{2}{|c|}{ Control } & \multicolumn{2}{|c|}{ IMF } & $\begin{array}{l}\text { Control } \\
\text { (overall) }\end{array}$ & $\begin{array}{c}\text { IMF } \\
\text { (overall) }\end{array}$ & SEM & \multicolumn{2}{|c|}{$P$-value } \\
\hline \multicolumn{10}{|l|}{ Precalving BCS } \\
\hline 1 & 4.1 & 4.1 & 4.0 & 4.0 & 4.1 & 4.0 & 0.1 & 0.48 & 0.84 \\
\hline 2 & 3.9 & 3.7 & 3.9 & 3.6 & 3.8 & 3.8 & 0.1 & 0.89 & 0.02 \\
\hline 3 & 3.3 & 3.9 & 4.1 & 4.0 & 3.6 & 4.0 & 0.1 & 0.04 & 0.29 \\
\hline All farms & 3.5 & 3.1 & 3.4 & 3.2 & 3.3 & 3.3 & 0.1 & 0.96 & $<0.01$ \\
\hline 1 & 3.7 & 3.5 & 3.7 & 3.5 & 3.6 & 3.6 & 0.1 & 0.88 & 0.14 \\
\hline 2 & 3.4 & 2.9 & 3.1 & 3.1 & 3.1 & 3.1 & 0.1 & 0.98 & 0.04 \\
\hline 3 & 3.2 & 2.5 & 3.2 & 2.8 & 2.9 & 3.0 & 0.1 & 0.66 & 0.01 \\
\hline 4 & 3.3 & 3.8 & 3.5 & 3.4 & 3.5 & 3.4 & 0.1 & 0.67 & 0.30 \\
\hline \multicolumn{10}{|l|}{ Midlactation $\mathrm{BCS}^{5,7}$} \\
\hline All farms & 3.3 & 2.9 & 3.1 & 3.0 & 3.1 & 3.0 & 0.1 & 0.46 & $<0.01$ \\
\hline All farms & 9.9 & 10.7 & 10.8 & 13.4 & 10.3 & 12.1 & 1.3 & $<0.01$ & $<0.01$ \\
\hline 1 & 9.8 & 13.1 & 11.5 & 16.8 & 11.5 & 14.1 & 1.4 & 0.17 & 0.03 \\
\hline 2 & 10.2 & 9.9 & 8.7 & 14.3 & 10.1 & 11.5 & 1.0 & 0.32 & 0.06 \\
\hline 3 & 10.1 & 10.1 & 13.5 & 11.2 & 10.1 & 12.3 & 1.0 & 0.10 & 0.39 \\
\hline 4 & 10.8 & 10.2 & 11.4 & 10.4 & 10.5 & 10.9 & 0.6 & 0.56 & 0.30 \\
\hline \multicolumn{10}{|l|}{ NEFA, $\mu \mathrm{Eq} / \mathrm{L}$} \\
\hline All farms & 347.7 & 502.0 & 423.1 & 544.1 & 424.9 & 483.6 & 38.8 & 0.08 & $<0.01$ \\
\hline 1 & 337.2 & 552.2 & 403.1 & 608.8 & 444.7 & 506.0 & 198.0 & $<0.01$ & $<0.01$ \\
\hline 2 & 328.8 & 494.0 & 423.6 & 503.4 & 411.4 & 463.5 & 33.7 & 0.26 & 0.01 \\
\hline 3 & 262.8 & 629.9 & 252.9 & 547.0 & 446.3 & 399.9 & 64.6 & 0.60 & $<0.01$ \\
\hline 4 & 510.2 & 295.2 & 626.5 & 492.7 & 402.7 & 559.6 & 51.2 & 0.03 & 0.02 \\
\hline
\end{tabular}

${ }^{1}$ Lact $=$ lactation.

${ }^{2} \mathrm{Trt}=$ treatment; refers to differences between treatments when cows from both lactation groups are included.

${ }^{3}$ Refers to differences between lactation groups when cows from both treatments are included.

${ }^{4}$ Farm was used as a covariate for this analysis.

${ }^{5}$ Precalving BCS was used as a covariate for this analysis.

${ }^{6}$ Early-lactation BCS refers to BCS taken during the first month postcalving.

${ }^{7}$ Midlactation BCS refers to BCS assessed between the 2nd and 4rd month of lactation with $88 \pm 8$ DIM for all farms. 
Table 5. Relative risk for cows to be classified as subclinically ketotic for cows (from the 4 farms) that were milked $4 \times$ (increased milking frequency, IMF) for the first $21 \mathrm{~d}$ postpartum, followed by $2 \times$ for the remainder of the lactation compared with cows milked $2 \times$ (control) during their entire lactation

\begin{tabular}{lccc}
\hline Farm & $\begin{array}{c}\text { Relative } \\
\text { risk }^{1}\end{array}$ & CI & $\begin{array}{c}\text { Chi-square } \\
\text { P-value }\end{array}$ \\
\hline All & 1.4 & $1.2-1.8$ & $<0.01$ \\
1 & 1.5 & $1.1-2.2$ & 0.01 \\
2 & 1.3 & $0.8-2.0$ & 0.26 \\
3 & 1.5 & $0.9-2.5$ & 0.09 \\
4 & 1.1 & $0.6-1.9$ & 0.70 \\
\hline
\end{tabular}

${ }^{1}$ The threshold used to classify an animal as at risk for subclinical ketosis was BHBA values $>10 \mathrm{mg} / \mathrm{dL}$

tion $(35.6$ vs. $34.1 \pm 0.6 \mathrm{~kg} / \mathrm{d}$; Table 3$)$. In addition, farm 2 implemented an additional treatment in which cows were milked $4 \times$ for $60 \mathrm{~d}$ postpartum. Milk yield was increased for cows milked $4 \times$ for $60 \mathrm{~d}$ compared with controls $(37.0$ vs. $34.1 \mathrm{~kg} / \mathrm{d} ; P<0.01)$. These results suggested that increasing the period of IMF from 21 to $60 \mathrm{~d}$ increased the overall response to IMF. Other studies have analyzed periods of IMF within the same study. VanBaale et al. (2005) determined that $6 \times$ milking for 7,14 , or $21 \mathrm{~d}$ postpartum did not affect responses to IMF; however, facility and grouping management considerations likely complicated any potential response to IMF in their study. The other study was conducted using a unilateral milking design and it was concluded that the response to IMF was similar for cows frequently milked for $14 \mathrm{~d}$ from d 1 to 14 of lactation or frequently milked from d 7 to 21 of lactation, and both milk responses were similar to half udders frequently milked from d 1 to 21 of lactation (Wall and McFadden, 2007b).

On farm 3, IMF increased overall milk yield during the first 7 monthly test days by $1.8 \mathrm{~kg} / \mathrm{d}(30.7$ vs. 28.9 $\pm 0.6 \mathrm{~kg} / \mathrm{d} ; P=0.05$; Table 3$)$. This farm had the highest increase in milk yield by primiparous cows $(2.4 \mathrm{~kg} / \mathrm{d}$ over control cows); at this farm, all cows were housed in a tie-stall barn during the first $21 \mathrm{~d}$ postpartum; therefore, primiparous cows did not experience any competition for feed or resting space during the period of IMF. These findings support Soberon et al. (2010), in which primiparous cows housed in a tie stall-barn had a higher response to IMF than did multiparous cows.

Farm 4 interrupted the study by switching all cows to $3 \times$ milking 6 mo after beginning the experiment, so the data from this farm were analyzed using only the first 5 monthly test days of lactational data per cow. Overall milk yields were not different in IMF versus control cows ( 37.1 vs. $35.1 \pm 1.0 \mathrm{~kg} / \mathrm{d} ; P=0.18)$. An interaction of treatment by month existed for this farm $(P<0.01)$ in that cows subjected to early lactation
IMF had increased milk yield during the first month of lactation, but did not have a carryover effect.

Results for prepartum and postpartum BCS and serum concentrations of key energy metabolites (BHBA and NEFA) are in Table 4. Precalving BCS was used as a covariate for analysis of postpartum BCS. Overall, differences between treatments during early (the first $21 \mathrm{~d}$ postpartum) or midlactation $(88 \pm 8$ DIM $)$ and the interactions of treatment with lactation group were not significant. Differences in postpartum BCS within farm were not significant for any of the farms. These findings support Hale et al. (2003) and Soberon et al. (2010), who did not observe differences in BCS in cows subjected to early lactation IMF compared with controls.

Serum samples collected within the first $21 \mathrm{~d}$ postcalving were analyzed for concentrations of BHBA and NEFA. Overall, cows subjected to early lactation IMF had elevated circulating concentrations of BHBA (12.1 vs. $10.3 \pm 1.3 \mathrm{mg} / \mathrm{dl}, P=0.03$; Table 4 ); When the data was analyzed for the relative risk of being classified as subclinically ketotic, animals subjected to IMF were 1.4 times more likely to have blood BHBA concentrations above $10 \mathrm{mg} / \mathrm{dL}$ than animals in the control group $(P$ $<0.01$; Table 5). These overall results are consistent with those of Soberon et al. (2010). Concentrations of circulating NEFA tended to be increased by IMF (427 $\pm 38.8 \mu \mathrm{Eq} / \mathrm{L}$ for control vs. $485 \pm 38.8 \mu \mathrm{Eq} / \mathrm{L}$ for IMF; $P=0.08$; Table 4$)$. The proportion of cows with NEFA $>700 \mu \mathrm{Eq} / \mathrm{L}(19 / 145$ for control vs. 29/160 for IMF; $P=0.23$ ) was not affected by treatment (Table 6 ). Therefore, the milk yield increase in the IMF group was accompanied by an increase in subclinical ketosis. The analyses of BHBA and NEFA plasma concentrations and the proportion of cows categorized as subclinically ketotic or with high NEFA were done by farm (Tables $4,5$, and 6$)$. Although differences existed among farms for the concentrations and relative risk for elevated concentrations of BHBA and NEFA, these differences do not appear associated with magnitude of response.

Table 6. Relative risk for cows to be classified as having high NEFA concentrations for cows (from the 4 farms) that were milked $4 \times$ (increased milking frequency, IMF) for the first $21 \mathrm{~d}$ postpartum, followed by $2 \times$ for the remainder of the lactation compared with cows milked $2 \times($ control $)$ during their entire lactation

\begin{tabular}{lccc}
\hline Farm & $\begin{array}{c}\text { Relative } \\
\text { risk }^{1}\end{array}$ & CI & $\begin{array}{c}\text { Chi-square } \\
P \text {-value }\end{array}$ \\
\hline All & 1.4 & $0.8-2.3$ & 0.23 \\
1 & 1.5 & $0.6-3.8$ & 0.36 \\
2 & 1.0 & $0.3-3.0$ & 1.00 \\
3 & 0.9 & $0.4-2.3$ & 0.85 \\
4 & 4.6 & $0.8-28.5$ & 0.21 \\
\hline
\end{tabular}

${ }^{1}$ The threshold for classifying an animal as at risk for having high NEFA values was NEFA $>700 \mu \mathrm{Eq} / \mathrm{L}$. 
The exception to this might be the primiparous cows on farm 4, which had higher concentrations of circulating NEFA than did multiparous cows and had a negligible response to IMF. The primiparous cows on farm 4 were housed in the same pen as multiparous cows and this farm had the highest stocking density for fresh cows of any of the 4 farms (stocking density above 100\% at the feed bunk). Overcrowding of primiparous cows postcalving in a pen with multiparous cows may be the reason why this group of cows had elevated NEFA levels as well as lower responses to IMF.

\section{CONCLUSIONS}

Early lactation IMF for the first $21 \mathrm{~d}$ postpartum resulted in overall increases in yields of milk and milk components on commercial dairy farms varying in both overall management schemes and with minimum milking intervals ranging from 3.5 to $6 \mathrm{~h}$. Increasing the duration of IMF to $60 \mathrm{~d}$ on 1 farm resulted in increased responses to IMF. In contrast to previous reports, early lactation IMF did not affect udder health as assessed by changes in somatic cell linear score. Early-lactation IMF did not appear to affect BCS during early lactation; however, it increased the concentrations of serum BHBA during the postpartum period and increased the relative risk of subclinical ketosis. In conclusion, earlylactation IMF has the potential to increase yields of milk and milk components and has the potential for robust responses across dairy farms.

\section{ACKNOWLEDGMENTS}

We gratefully acknowledge the participation of the New York dairy farms in this study. Partial support of this research was provided by Federal Formula Funds allocated to and administered by the Cornell University Agricultural Experiment Station (Geneva, NY).

\section{REFERENCES}

AOAC. 2000. Official Methods of Analysis. 17th ed. Association of Official Analytical Chemists, Arlington, VA.

Bar-Peled, U., E. Maltz, I. Bruckental, Y. Folman, Y. Kali, H. Gacitua, and A. R. Lehrer. 1995. Relationship between frequent milking or suckling in early lactation and milk production of high producing dairy cows. J. Dairy Sci. 78:2726-2736.
Barnes, M. A., R. E. Pearson, and A. J. Lukes-Wilson. 1990. Effects of milking frequency and selection for milk yield on productive efficiency of Holstein cows. J. Dairy Sci. 73:1603-1611.

Chapa, A. M., J. M. Fernandez, D. L. Thompson Jr., R. J. Tempelman, L. F. Berrio, W. J. Croom Jr., and W. M. Hagler Jr. 1995 Endocrine and metabolic response to muscarinic stimulation and inhibition in the ruminant: Effects of slaframine. J. Anim. Sci. 73:3673-3680.

Dahl, G. E., R. L. Wallace, R. D. Shanks, and D. Lueking. 2004. Hot topic: Effects of frequent milking in early lactation on milk yield and udder health. J. Dairy Sci. 87:882-885.

Dean, A. G., J. A. Dean, D. Colombier, A. H. Burton, K. A. Brend, D. C. Smith, R. C. Dicker, K. M. Sullivan, and R. F. Fagan. 1994 Epi Info, Version 6: A Word Processing Database and Statistics Program for Epidemiology on Microcomputers. Centers for Disease Control and Prevention, Atlanta, GA.

Erdman, R. A., and M. Varner. 1995. Fixed yield responses to increase milking frequency. J. Dairy Sci. 78:1199-1203.

Fernandez, J., C. M. Ryan, D. M. Galton, and T. R. Overton. 2004. Effects of milking frequency during early lactation on performance and health of dairy cows. J. Dairy Sci. 82(Suppl. 1):424. (Abstr.)

Hale, S. A., A. V. Capuco, and R. E. Erdman. 2003. Milk yield and mammary growth effects due to increased milking frequency during early lactation. J. Dairy Sci. 86:2061-2071.

Klei, L. R., J. M. Lynch, D. M. Barbano, P. A. Oltenacu, A. J. Lednor, and D. K. Bandler. 1997. Influence of milking three times a day on milk quality. J. Dairy Sci. 80:427-436.

McCutcheon, S. N., and D. E. Bauman. 1986. Effect of chronic growth hormone treatment on responses to epinephrine and thyrotropinreleasing hormone in lactating cows. J. Dairy Sci. 69:44-51.

Ospina, P. A., D. V. Nydam, T. Stokol, and T. R. Overton. 2010 Evaluation of nonesterified fatty acids and $\beta$-hydroxybutyrate in transition dairy cattle in the northeastern United States: Critical thresholds for prediction of clinical diseases. J. Dairy Sci. 93:546-554.

SAS Institute. 2010. SAS/STAT User's Guide: Statistics, Version 9. SAS Inst. Inc., Cary, NC.

Smith, J. W., L. O. Ely, W. M. Graves, and W. D. Gilson. 2002. Effect of milking frequency on DHI performance measures. J. Dairy Sci. 85:3526-3533.

Soberon, F., J. L. Lukas, M. E. Van Amburgh, A. V. Capuco, D. M. Galton, and T. R. Overton. 2010. Effects of increased milking frequency on metabolism and mammary cell proliferation in Holstein dairy cows. J. Dairy Sci. 93:565-573.

VanBaale, M. J., D. R. Ledwith, J. M. Thompson, R. Burgos, R. J. Collier, and L. H. Baumgard. 2005. Effect of increased milking frequency in early lactation with or without recombinant bovine somatotropin. J. Dairy Sci. 88:3905-3912.

Wall, E. H., and T. B. McFadden. 2007a. The milk yield response to frequent milking in early lactation of dairy cows is locally regulated. J. Dairy Sci. 90:716-720.

Wall, E. H., and T. B. McFadden. 2007b. Optimal timing and duration of unilateral frequent milking during early lactation of dairy cows. J. Dairy Sci. 90:5042-5048.

Wall, E. H., and T. B. McFadden. 2008. Use it or lose it: Enhancing milk production efficiency by frequent milking of dairy cows. J. Anim. Sci. 86:27-36.

Wildman, E. E., G. M. Jones, P. E. Wagner, R. L. Boman, H. F. Troutt Jr., and T. N. Lesch. 1982. A dairy cow body condition scoring system and its relationship to selected production characteristics. J. Dairy Sci. 65:495-501. 